\title{
How to Develop Collaboration in Drug Development Process: The Role of Professional Service Firms
}

\author{
Rosangela Feola ${ }^{1}$, Valentina Cucino $^{2} \&$ Roberto Parente ${ }^{3}$ \\ ${ }^{1}$ Department of Management and Innovation System, University of Salerno, Fisciano (SA), Italy and IPAG \\ Business School (Paris, France) \\ ${ }^{2}$ Scuola Superiore Sant'Anna, Institute of Management and Department EMbeDS, Pisa, Italy \\ ${ }^{3}$ Department of Management and Innovation System, University of Salerno, Fisciano (SA), Italy \\ Correspondence: Rosangela Feola, Department of Management and Innovation System, University of Salerno \\ (Italy), Via Giovanni Paolo II, 132 - 84084 Fisciano (SA), Italy and IPAG Business School (Paris, France).
}

Received: January 15, 2021

Accepted: February 18, 2021

Online Published: March 29, 2021

doi:10.5539/ibr.v14n4p114

URL: https://doi.org/10.5539/ibr.v14n4p114

\begin{abstract}
The innovation chain of the pharmaceutical industry is more and more complex. In particular, a new type of players, the start-ups founded by researchers (Academic Start-ups) have proven to be particularly effective in the first steps of exploring new, radically innovative technologies. These small start-ups miss the financial resources and the industrial experience necessary to embark in the later stage of technologies' development. To overcome these limits, what academic start-ups require the most is a collaborative linkage with large biotech and pharma companies. To such end, Business Development Professionals are offering their services to academic start-ups, to set up a collaborative linkage with potential partners. Our article investigates the process of engagement between Academic Start-ups and Business Development Professionals and in particular, we focus on the factors that influence collaboration between the two actors. In order to investigate the development process of collaboration we conducted an exploratory study trough the submission of a semi-structured questionnaire covering different aspects of the engagement process to a sample of business professionals. The study provide first evidences about the main factors that prevent the development of collaborations and provides some suggestions to overcome the challenges that both parts found in the collaboration process.
\end{abstract}

Keywords: open innovation, life science sector, academic start-up, business developer, collaboration.

\section{Introduction}

In the last decades, the life sciences industry has been characterized by structural changes making it as a privileged scenario for the rise of open innovation approaches in R\&D strategies (Chesbrough et al., 2006); Wikhamn \& Styhre, 2017)). In recent years, investments in research and development have significantly increased, while the rate of growth of successful products going on the market is not following the same pace (Ernst \& Young, 2018; Jacobs et al., 2015). To face these radical structural changes, pharmaceutical companies are undertaking strategic shifts to increase their R\&D effectiveness. The pharmaceutical industry represents in fact an emblematic case in which firms have pursued a new strategy adopting new technological trajectories and transforming existing technological identity and capabilities (Kale, 2012). Such strategies include: (1) focus the innovation project portfolio on core technologies and/or on a specific phase of projects development (Schuhmacher et al., 2016); (2) reduce and re-organize the R\&D internal organizational structures (Schuhmacher et al. (2016) and moreover, (3) open to outside partnership to rise the potential for innovation (Schuhmacher et al., 2013).

From a strategic point of view, this has ended in a radical re-definition of their model of innovation (Powell et al., 1996; Chesbrough, 2006)).

The traditional model of closed innovation, predominant in the last decades and in which the innovative activities were mainly carried out in-house, has been replaced by an Open Innovation model in which the collaboration between many different players in the innovation process is the key element (Chesbrough \& Crowther, 2006). As a result, the pharmaceutical industry' value chain is now more disaggregated than in the past allowing different players to specialize in different phases of new products' development (Khanna, 2012). 
According to several studies, innovation in life sciences is based on the coordinated efforts of three types of organizations: university, start-up and established life science companies (Arora et al., 2000; Baron \& Kenny, 1986; Powell et al., 1996; Zucker et al., 2002; Gertler \& Vinodrai, 2009; Ahn et al., 2013).

In this context Big Pharma, have progressively focused themselves in the final stages of clinical trials of new drugs, new research-based business ventures have quickly become a key player in the first development phases, like drug discovery phase and preclinical validation (Papa et al., 2020). This kind of strategy is also in line with the literature about the concept of exploitation and exploration in innovation process (March, 1991) where exploration focuses on exploring new opportunities, which are generally riskier and more long-term oriented, while the other one focuses on improving the well-established and already profitable products and capabilities. What we can observe is a tendency in established firms to focus more on the exploitation of the existing capabilities, and less on risky explorations of new opportunities (Alizadeh \& Jetter, 2019).

A large body of empirical research provides evidence that a more balanced investment in both exploitation and exploration activities increases the survival of firms and also improves other performance measures such as sales growth, market valuation, and innovation.

On the other side, hybrid organizations, like Academic Start-ups (ASUs), i.e companies founded by academic researchers with the aim to explore new technological trajectories coming from scientific discoveries, in particular, have proven to be particularly capable of grasping the entrepreneurial opportunities of these changes (Powell et al., 1996; Fudickar \& Hottenrott, 2019).

Founded by researchers, and supported by their Universities (Rao \& Mulloth, 2017) as a mean of an effective technology transfer policy (Sheriff \&Muffatto, 2018; Piccaluga, 2001; Smith et al., 2008), these small academic start-ups have valuable scientific and technical experience, lower fixed costs, less bulky organizational structures and strong focus on one (or a few) specific areas. As a result, these companies have demonstrated the ability to make incredible scientific advancements (Wilson, 2008)) and are playing a key role in creating new knowledge and disruptive new technologies in Life Science (Tahvanainen, 2004).

Thanks to their previous scientific knowledge, and sometimes with the support of Venture Capital specialized in high-risk investments, these spin-offs have proved particularly effective in the identification and preclinical validation of a new therapeutic target.

Notwithstanding the significant advantages of cooperation in R\&D processes the connection between ASU and large pharma has always been difficult because of deep cultural differences between the two (Cooke, 2003). Further, it has recently become more and more difficult because of the increasing evaluation standard applied by Big Pharma for investing in new projects coming from start-up (Onetti \& Zucchella, 2014). Contract Research Organizations (CROs) and Business Development Professionals (BDPs) are therefore gaining an important role proposing themselves as a bridging point between start-up and large pharma (Parente et al., 2016). As highlighted by some scholars, in open innovation context, intermediaries can play a strategic role (Ebersberger et al., 2012; Hossain, 2012; Ndou et al., 2011). Studies have pointed out that the role of intermediary creates the necessary linkages between the many actors in an innovation network (Klerkx \& Leeuwis, 2008). Weng et al. (2017) show that innovation intermediaries can act as a bridge between different competency constraints among companies and can help firms in developing collaborations (Weng et al., 2017). The strategic position of the intermediary can activate different resources from the ones embedded in an alliance network.

Starting from these premises, the purpose of this study is to examine the interaction between academic based start-ups and BDPs in life science industry. In particular, we are going to focus on the main factors that prevent or hinder collaboration between ASUs and BPDs from the point of view of BDP.

The remainder of the paper is organized as follows. The second part describes the main partnering issues in Life Science. The third part describes the methodology and the research sample. The fourth and fifth part describe the results and implications of the research.

\section{Theoretical Framework}

\subsection{Early Stage Partnering Issues in Life Science Industry}

Start-ups and Academic based ventures have quickly become a key player in the drug discovery process. According to EY forecasts, Life Science start-ups will absorb between 30 and 45 percent of the market by 2030 (Ernst \& Young, 2018).

The business model of ASUs, with few exceptions, consists of nurturing their technologies until the point where there is enough evidence on their soundness from the scientific, marketing and industrial points of views. At that 
moment in time, a negotiation process will start to sell the technology and related Intellectual Property to a big pharma that has capital and experience to sustain later stage of development and marketing of the new product. Start-ups that access external knowledge through alliances increase their ability to learn new skills and to overcome competency traps (Rosenkopf \& Almeida, 2003; Vega-Jurado et al., 2009). For example, the literature agrees that alliances are a means by which companies acquire knowledge and learn new skills (Powell et al., 1996; Prahalad et al., 1990).

On the other side, the revolution in the life sciences changed the organizational and managerial aspects of drug research; it changed the internal structure of R\&D processes realized by Big Pharma by increasing emphasis on collaboration, publication, and willingness to exploit external sources of technology (Cockburn, 2004). Large pharmaceutical firms focused on internal R\&D transformation primarily by hiring new personnel, embracing new technology and incorporating these into existing structures. They promoted collaboration and joint ventures with university scientists and new biotechnology firms to increase their internal expertise (Zucker \& Darby, 1997).

Nicholls-Nixon (1993) points outs that large pharmaceutical firms developed new capabilities by investing in biotechnology-related R\&D activities and by accessing new external technological linkages. According to Galambos et al. (1998) some pharmaceutical firms used different approach in collaborating with biotech firms. In some case Big Pharma adopt an incremental approach of working in order to develop in-house biotechnology capability, while other firms used the acquisitions as mean to acquire external competences and resources. Supporting this observation Gambardella (1995) explained that large pharmaceutical companies employed different mechanisms of knowledge transfer from university to complement internal capabilities in biotechnology. The author identifies four kind of mechanisms: research and/or joint development agreements with other firms, research agreements with universities, investments in the capital of biotechnology firms, and acquisitions of small biotech coming generally coming from the university itself. Such changes led to the transformation of new drug discovery and development in pharmaceutical and life science sector with the passage from a totally in-house activity to a networked activity.

There is clear evidence that recently Big pharma are becoming more selective about such kind of technology transfer transactions, becoming more challenging about quantity and quality of data to be provided as a Proof of concept necessary to close the deal. Nowadays having completed, or near to complete, a successful pre-clinical phase, is the necessary level of development for ASU to become attractive for a big pharma. A live-or-die question for the ASU but at the same time a very challenging issue.

From one side, that change means more capital needed for ASU, and on the other side this imply a strategic challenge for ASU regarding the most effective key activities and development pathways to attract attention from big pharma. In fact, while later Clinical Phases in the Drug development process are quite well defined, due to strict regulation rules that oversee the possibility to go forward, the Drug Discovery and the Pre-clinical phases are not. This means that judgment from the targeted buyers of the technology is the only benchmark against which pre-clinical projects struggle to demonstrate their proof of concept validity. In other words, due to the Industry's organisation, the first stages of a validation process of a new therapeutic target takes shape inside an entrepreneurial subject (the ASU) that don't know ex-ante who will judge its robustness and according to which criteria they will express their judgment.

Cognitive representation of rugged competitive landscapes (Levinthal \& Warglien, 2008) of the pharma industry is, therefore, a key competence for a start-up to better assess the entrepreneurial opportunity of new technology and to represent a clear model of relationships between investments and expected profits. The problem is exacerbated by the team composition of the ASUs, that often miss basic management competencies (Visintin \& Pittino, 2014)).

To overcome these difficulties, "in most cases, what start-ups need most is something akin to "mentorship" from industry's experts (Wilson, 2008)). Furthermore, for those ASUs having on board an external investor, an experienced mentor has in itself a signaling effect that raise attention of big pharma (Festel, 2011)).

This is why growing numbers of professionals try to intercept the entrepreneurial teams in a more or less early stage of their development process in order to help them in arranging their best pathway to a potential deal for the sale of the technology.

Business Developers, Strategic consultants and so on can offer the "cognitive representation" of a complex and fast evolving industry, putting their expertise in order to address and sustain the development of new ASUs effectively. 
However, also if plenty of opportunities, matching between these two kinds of subjects, ASU and BDP, is not simple to realize.

Integration of scientific and management expertise in the early stage of $R \& D$ process is quite complicated and notwithstanding some excellent experiences in the US and Europe about the so-called "Founding Angels" (Festel (2011)), this integration often remains a will. Several studies have concentrated knowledge flow and stock on innovative success but few have investigated the factors that hinder the collaboration between companies.

Starting from these premises, the purpose of this study is to examine the interaction between ASU and BDP. In particular, we are going to examine the main factors that prevent or hinder collaboration. What are the main pitfalls in entrepreneurial cooperation?

\section{Method}

Due to the limited research on the relationship between academic based start-up and BDP in life science industry, we have chosen to conduct an exploratory study (Yin, 1989).

The starting point was the preparation of a semi-structured questionnaire covering different aspects of the engagement process of a BDP by an ASU. The semi-structured interview protocol was pre-tested with five experts, including three BDPs and two experts of Life Science R\&D. Respondents were randomly selected. Interviews averaged one hour in duration, with a range of 30 to 70 minutes.

As a result of that pre-test interviews, a final questionnaire was ready and divided into four parts. In the first part, the BDP is requested to describe his company and its business model. In the second part the interviewee describes his preferred way to approach an academic start-up. The third part investigates what start-ups are looking for when approaching an external consultant. The fourth part investigates the main obstacles for a BDP to cooperate with an ASU.

\subsection{Data Collection}

Interviews, based on the semi-structured questionnaire, were made by the third author during the event of Bioeurope 2017. This event was chosen because it represents the main International Partnering Conference for the biotech industry in Europe (https://www.ebdgroup.com/events/). The event brings together the main players in the biotech, pharmaceutical and financial world and represents a high-level partnership opportunity. During a 3 days event, workshops, seminar, and above all, thousands of one-to-one meetings between start-up, professionals and Big pharma. Bioeurope is a "must to attend" event for everyone involved in the life science R\&D processes and looking for partnership and deal making. On the web site of Bioeurope, attendees can select experts and companies they want to meet during the 3 days fair. Navigating in the directory of Bioeurope 2017, 246 BDPs were identified, and to each of these an email was sent presenting the research goal and a request to complete an attached Questionnaire. 36 BDPs were responding positively to this request sending back the Questionnaire completed (14.6\%).

\subsection{Data Analysis}

Data were normalized with respect to the average of the responses to ensure that all variables are proportionate to each other. The normalization process is based on the standardization of the variables, that is, on the transformation of the variables carried out through the relation where xi is a generic value of the distribution of the random variable $\mathrm{X}$ and $\mu$ and $\sigma$ respectively represent the mean and the root mean square of the original distribution. The values of the data thus transformed assume a distribution called the standard normal distribution, which is characterized by the fact that 1) their arithmetic mean is equal to zero; 2) their variance is equal to one. Thus, the results a) from 0 to +1 and from 0 and -1 are within the average of the answers b) higher than +1 are higher than the average of the answers, c) higher than -1 are lower than the average of the answers.

\section{Results}

The following session describes the results of the 36 Questionnaires. The session is divided into five parts according to the structure of the interview.

\subsection{Descriptive Data}

Interviews show that the majority of the BDPs are organized as a consultancy company. Many of them have even more than 10 employees and mainly focused on their national market (only some of them have branches outside the mother country). Scientific knowledge is a key feature of a BDP team, considering that most of them has one or more Phds in his Team. Respondents BDPs offer a broad range of services to their customers (most of respondents affirms they have a broad portfolio of services) (Fig.1). ASUs do have options on how to approach the market of professional services offered by BDPs. 17 BDPs affirms they follow a "Fee for services" business 
model, where 18 affirms they are open to consider a "Risk sharing approach" in working with an ASU. Risk sharing usually take the form of not charging completely the costs for services to the customers, in exchange for a percentage of revenues coming out from an event of future acquisition by a third part.

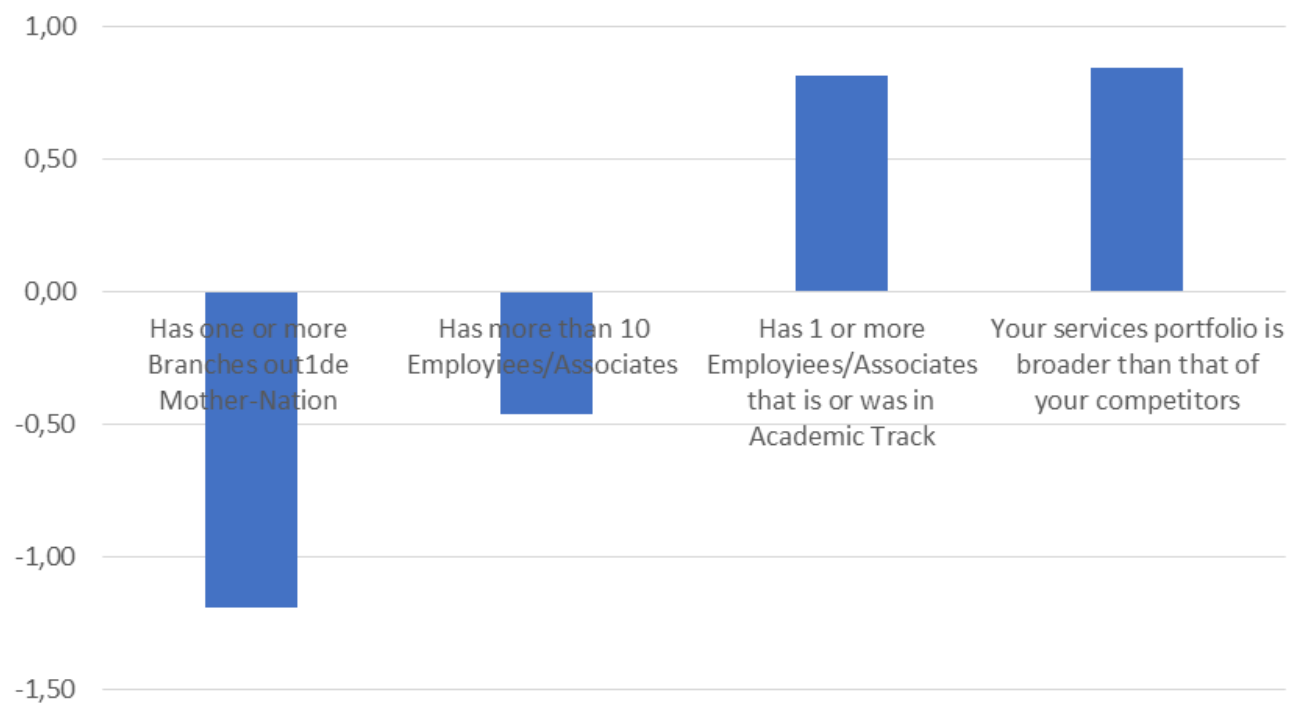

Figure 1. The composition of respondents

\subsection{Knowledge Limits of ASUs and Their Expectations in Approaching a BDP}

Two questions included in the questionnaires shed light on the perception of BDPs about the knowledge limits of ASUs. First, we ask the following question: "Do, According to your experience, academic start-up have a clear vision on. We tested 5 different areas of knowledge considered crucial for the ASUs success. Respondents can assign a value to each of the 5 areas of knowledge of an ASU according to their perceptions. The value assigned can range from 1 (very limited knowledge) to 7 (very high knowledge), and in fig. 2, the normalized mean of the values assigned to each areas of ASUs knowledge is reported. As shown, according to the BDPs expertise, ASUs have serious limits in all the five considered areas of knowledge. The minimum value assigned is for the issue of "How to approach and interact with a potential partner". The maximum value is for "Platform of services and technologies" to implement the development process (Fig. 2).

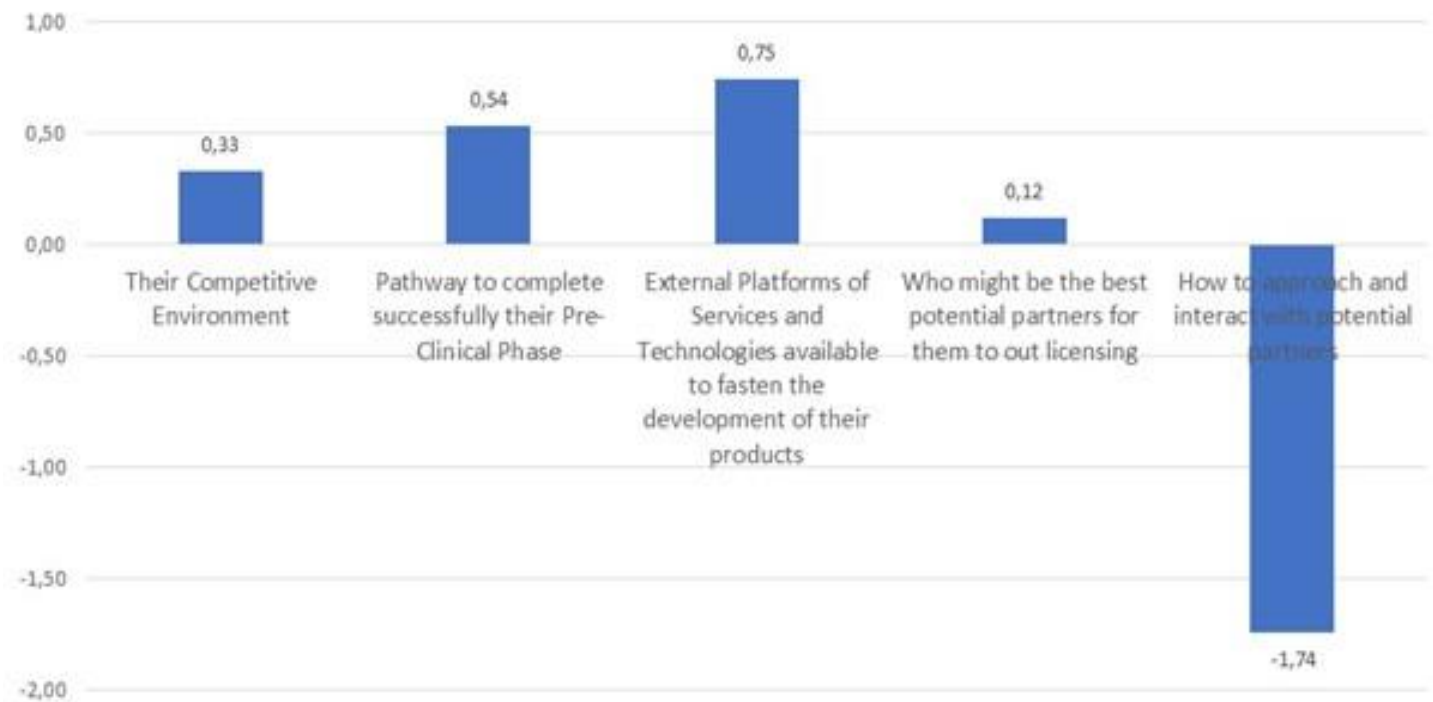

Figure 2. Level of the knowledge of ASUs 
As a control, we asked a question about what are ASUs' looking for when approaching a BDP, and the answers are coherent with the data shown above (Fig. 3). There are four elements sought by academic start-ups in BDP. For the majority of respondents the most requested help from academic start-ups their abilities to approach and interact with potential partners (1.34). Second, start-up approach external consultants because they looking for the introduction to potential in-licensing and investor partners (0.59). In minor cases, many respondents were approached, also, by academic start-ups looking for advice about how to optimize their product development process $(-0.0411)$, or about how to identify services and technologies that can help to develop their products (-1.169). Finally, for few BDPs the main request coming from academic start-ups is about a definition of a Competitive strategy at all (-0.72).

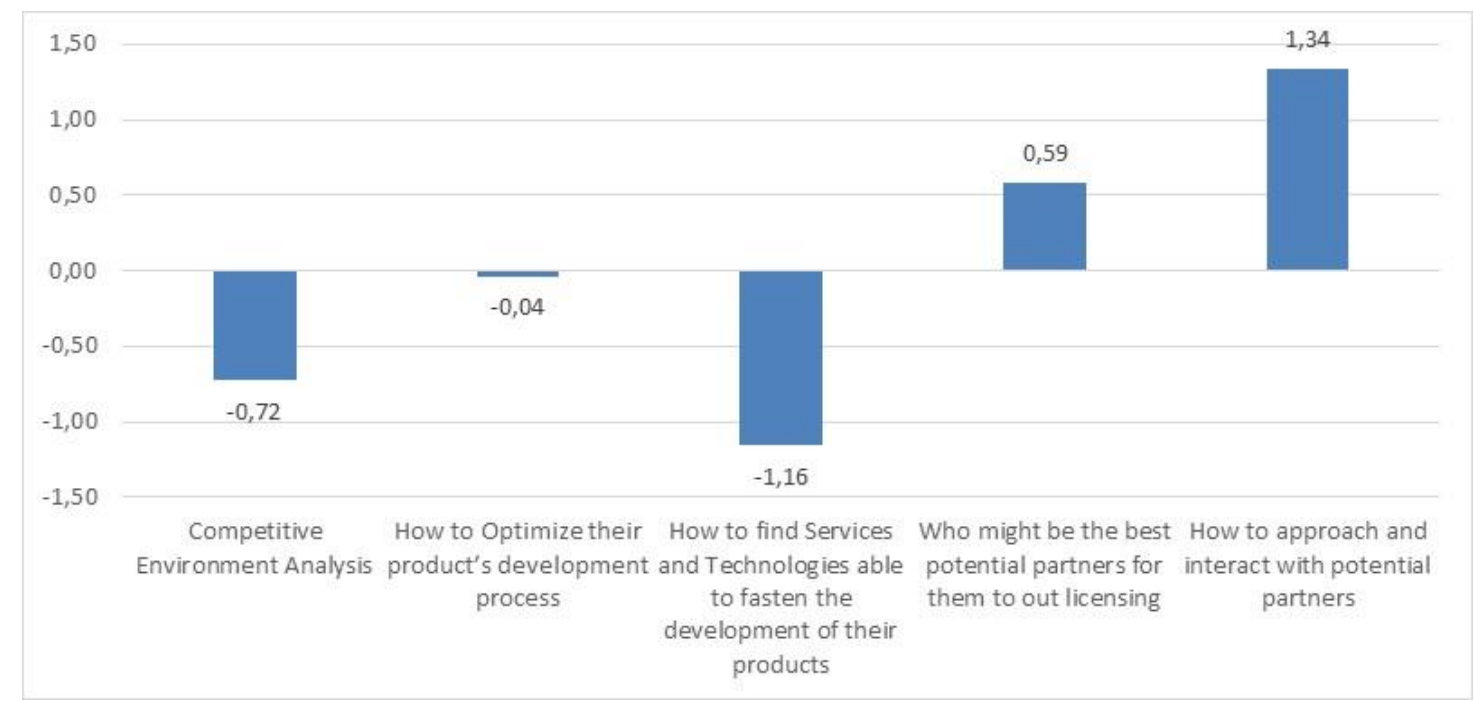

Figure 3. Services required from ASUs

\subsection{What ASU Consider Important in the Profile of a BDP}

We tested 7 different items to explain why an ASU hire a BDP (fig.4). The most important element considered is the track record of successful deals they have managed between their clients and Big Pharmas (1.11), end in particular their capability to effectively bridge with Industrial partners (0.97). Another element that an academic start-up takes into in great consideration in selecting the right BDP is a personal introduction by a third person (0.89). Relatively less important is the geographical proximity, the availability expressed by the BDP to share risks of new products development and the broad range of services offered. 


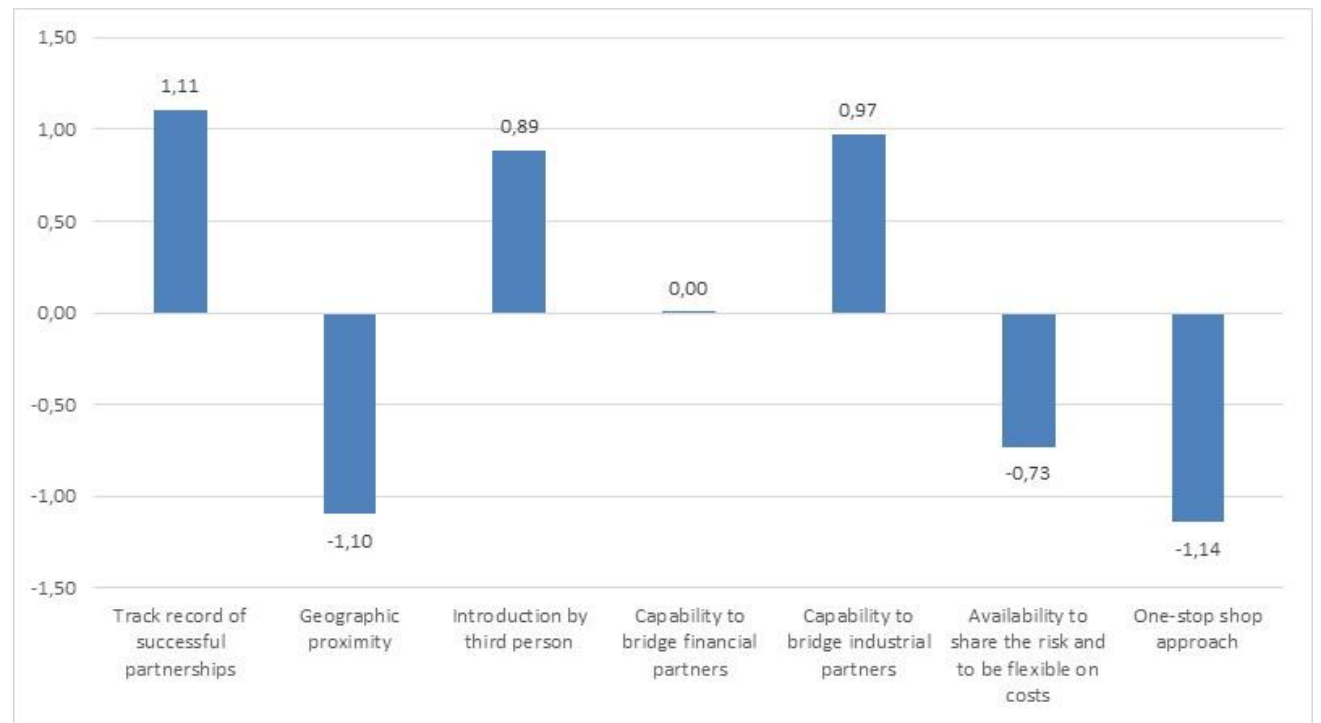

Figure 4. Most important elements to be hired by an ASUs

\subsection{What BDP Consider as Essential Prerequisite for a Risk Share Approach with an ASU?}

As pointed out, 18 BDPs have expressed their willingness to apply a risk sharing approach with their clients, investing alongside. These BDPs select the ASUs eligible for a risk sharing approach on the base of some specific requirements (Fig. 5). Excellence in science is the most important requisite to apply a risk sharing approach (14 out of 18 BDPs indicate as $\mathrm{n} .1$ or $\mathrm{n} .2$ requisite to consider eligible an ASU for risk sharing). Team strength (9 out of 18) and basic Managerial competencies (7 of 18) are less important but still collect a significant number of preferences by BDPs. On the contrary, Organizational Structure and availability to bear a Full time involvment in networking activity do not collect any quotation as n. 1 or n. 2 requirements.

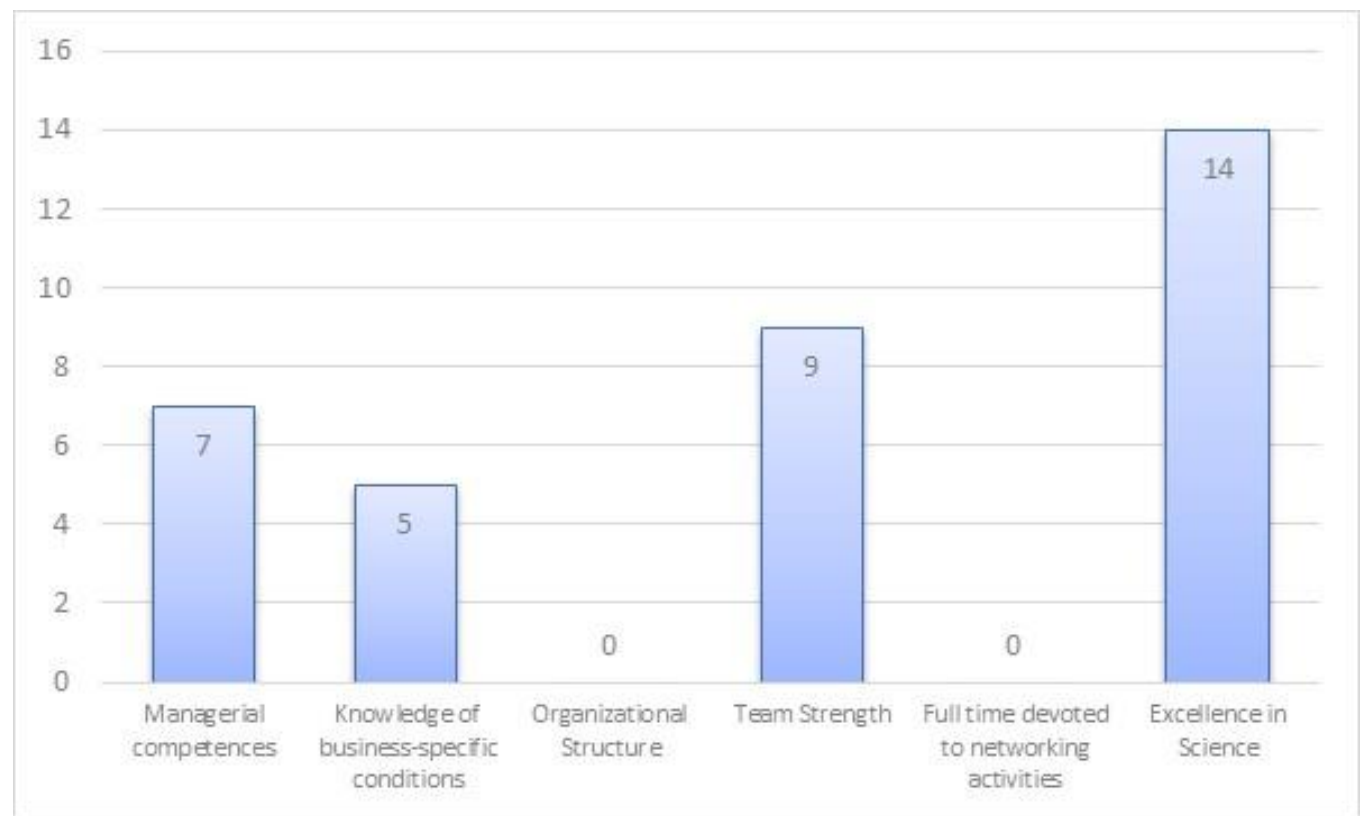

*Attributes which have been considered as $\mathrm{n} .1$ or $\mathrm{n} .2$ attributes when choosing an ASU eligible for a risk sharing approach by the 18 BDPs open to this business model

Figure 5. Attributes of an ASU to be eligible for a Risk sharing business approach 


\subsection{Why ASU and BDP Fail to Match?}

We investigated 6 main reasons why BDPs fail to establish a business connection with ASUs (Fig. 6). In the BDPs perceptions 3 obstacles are the most common ones. Lack of financial resources of ASU is recognized as important but not the most important reason ( 21 respondents choosed this item as $\mathrm{n}$. 1 or $\mathrm{n}$. 2 most important issue). The most often quoted perception is about the difficulties for an ASU to recognize the right value for the services offered by an external consultant ( 24 respondents report this as n. 1 or $n .2$ most important). Another very common answer is related to the issue of self-confidence of ASUs about their capability to stay alone in the business (18 times reported as n. 1 or n. 2 obstacle). On the other side, 3 other issues related to trust, to the willingness to share scientific knowledge and willingness to share strategic decisions, collect very few quotations (in total 8 quotations as n. 1 or n. 2 issue).

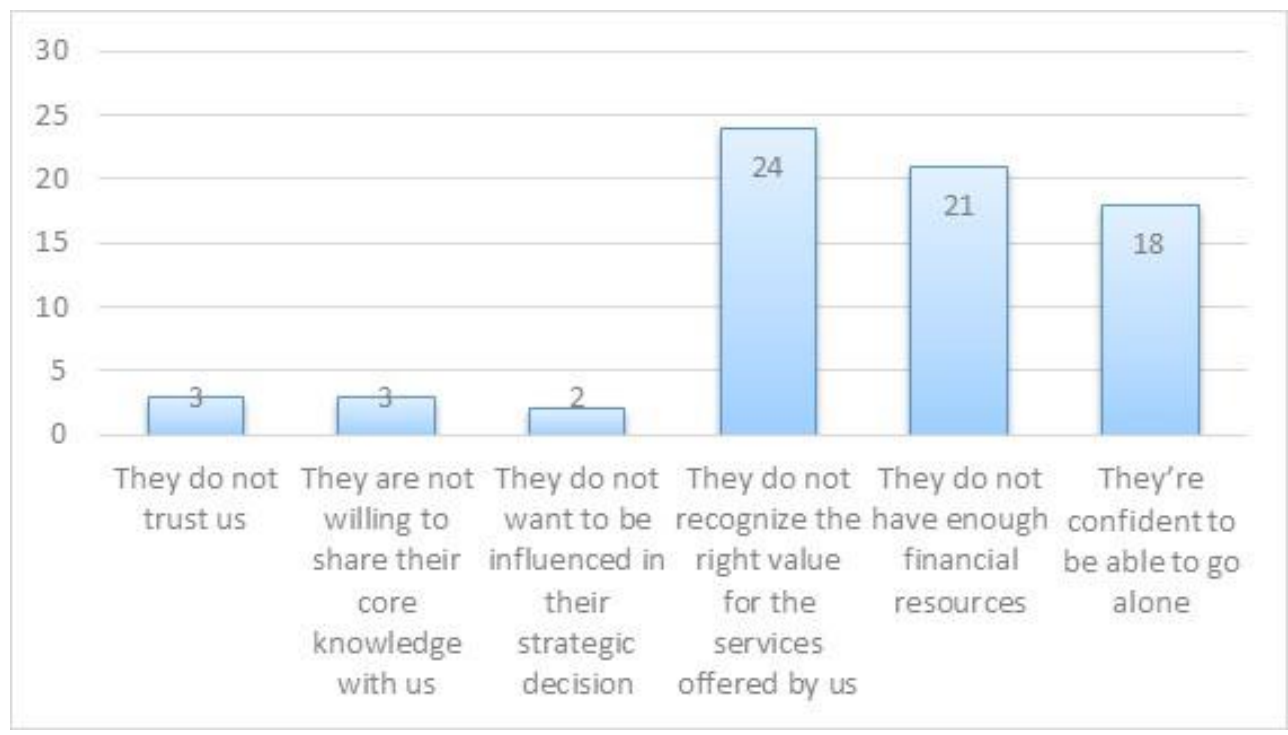

*Obstacles which have been considered as n. 1 or $\mathrm{n} .2$ Obstacle in the responses of the BDPs

Figure 6. Perception of obstacles to cooperate with ASUs

\section{Discussion: A Focus on the Nature of Obstacles for Cooperation between BDPs and ASUs}

The starting point of our study was the striking observation of the needs for ASUs to establish a strategic partnership with big pharma, from one side, and the difficulties they are experiencing to connect with BDPs that might have the competencies and relations to facilitate these partnerships. This study is exploratory in nature, focusing on various aspects of the perceived opportunities and difficulties in working with ASUs from the point of view of a group of BDPs. Starting from the data we collected from the questionnaire, we frame a possible explanation about the difficulties the BDPs are experiencing in establish a business connection with ASUs. In particular, we propose two distinct explanations of the pitfalls in BDPs/ASUs cooperation in drug development process:

- $\quad$ Different knowledge bases and limited absorption capacity (Zahra \& George, 2002);

- Different perspectives about distribution of incentives in a cooperation project (Kloyer \& Scholderer, 2012).

The first one concerns the different background and knowledge bases of ASUs from one hand, and external consultants, on the other. Coming from an academic context, the founders of ASUs (typically professor, researcher, $\mathrm{PhD}$ student, $\mathrm{PhDs}$ or research fellows), they generally own the technical and scientific background necessary to develop further the technology on which the firms is based. On the other side, they often suffer a technological myopia that is the inability to go further the technical and technological aspects of the project to capture the market and economic implications.

On the contrary, BDPs generally have significant experience in the industry that means networking capability to connect with key people in the business, but also that they have not the right skills to address and to face the technological uncertainties arising in the early stages of development of an ASU. 
The absorption problem emerges from informational asymmetry. More specifically, we can observe two kinds of informational asymmetry (Parente et al., 2011).

The first one is defined as 'hidden information' (Zeckhauser \& Kennedy, 2007) and refers to situation in which a part of the relationship is aware of information not known by the other part.

The second type of informational asymmetry could be defined as 'hidden action' and refers to situations in which a part of the relationship is not able to observe or verify actions realized by the other part (de Bettignies \& Brander, 2007). Both types of information asymmetry could result in a moral dilemmas and agency conflicts: the part that own the information has the interest to act according to self-interest, even if such actions generate high costs and risks for the other part (Amit et al., 1998). The agency conflicts could represent a disincentive for external subjects in participating in the academic spin-off.

About the second issue (distribution scheme of incentives and contracting forms), generally external consultant and/or business development manager, use a fee for services mechanism of payment.

This system is complicated to access for young start-ups because they often lack the financial resources necessary to acquire external services in order to develop the project and to transform a promising technology into a successful business.

This is particularly true in the initial stage of development because of the technological and market risks they have to face.

Technological uncertainties is a persistent issue in academic-based ventures. The technologies they propose generally introduce radical innovations that are characterized by a strong component of tacit knowledge and a general purpose (Harrison et al., 2004; Shane, 2004)). They represent a sort of technological platform that could be applied in different sectors and markets. For these reasons in the initial stage of development it is very difficult to identify from the beginning the possible technology developments and as a consequence it is very complicated to define since the beginning the real value of the entrepreneurial idea.

The market risk arises from the nature of the innovation that academic based start-up want introduce on the market. Those innovations are the result of scientific research (science push) and sometimes a market need does not yet exist for the invention but must be found (Shane, 2004).

The present study leads to some implications, both theoretical and practical. From a theoretical point of view, our study provides first evidence about the main factors that prevent the development of collaborations between Academic Start-ups and Business Development Professionals in drug development process.

From a practical point of view, our paper has shed light on the process of cooperation between Academic Start-Ups and Business Development Professionals and provides some suggestions to overcome the challenges that both parts found in the collaboration process. More specifically, a possibile solution to the issues arising in the cooperation process could be found in the definition of mechanisms of equity-based involvement of external subjects in the company. In this perspective, the prevision of a risk-sharing approach from external consultants could be an effective mechanism to facilitate collaboration between Academic Start-Up and Business Development Professional. Aware of their difficulties in attracting external financial resources, academic start-up is generally well disposed to integrate the entrepreneurial team, leaving an equity share of the company with the objective to acquire the necessary and missing competencies.

On the other hand, for external consultants, the assumption of entrepreneurial risk should be balanced through the definition of a mechanism of allocation of decision-making powers and the introduction of monitoring and incentive systems in order to enforce the commitment of the founders in the management of the innovation process.

\section{Conclusion}

Life science industry is experiencing a deep transformation. Innovation is the main driver of growth in the life science industry but in light of the great challenges that the life science industry has faced for several years - and in particular how to manage the stagnant productivity of research and development (R\&D) - pharmaceutical companies have opened their R\&D organizations to external innovation (Schuhmacher et al., 2013).

Nowadays, innovation in life sciences is based on the coordinated efforts of certain types of organizations: universities, start-ups and established life sciences companies (Gertler \& Vinodrai, 2009; Ovseiko et al., 2012). While Big Pharma have progressively focused on the final stages of clinical trials of new drugs, new research-based business initiatives have quickly become a key player in the early stages of development (e.g. the drug discovery phase and preclinical validation). Consequently, Big Pharma and incumbents in the industry are 
forced to restructure their R\&D processes, and they have been facilitated in that restructuring process by the rise of a new cohort of ASUs, which take care effectively of the first steps of development of a new therapeutic target. Although potentially very effective, establishing a partnership with a big pharma is difficult and is becoming more and more difficult, due to the changing preferences of the big pharma that now prefer to invest on later stage of pre-clinical development. BDPs are offering their service to bridge that gap, but still there are experiencing difficulties in connecting with ASU. Our paper has shed light on the process of cooperation between ASU and BDP and it can open the field for further and future research projects to understand in more details the role of bridging points and intermediaries in the full deployment of an open innovation strategy in a high tech industry.

\section{References}

Ahn, M. J., York, A. S., Sohn, S. Y., \& Benyamini, P. (2013). Biotechnology innovation: a legitimacy-based view. International Journal of Innovation Technology and Management, 10(4), 1-21. https://doi.org/10.1142/S0219877013500156

Alizadeh, Y., \& Jetter, A. J. (2019). Pathways for Balancing Exploration \& Exploitation in Innovations: A Review and Expansion of Ambidexterity Theory. International Journal of Innovation Technology and Management, 16(5), 1-33. https://doi.org/10.1142/S0219877019500329

Amit, R., Brander, J., \& Zott, C. (1998). Why do venture capital firms exist? theory and canadian evidence. Journal of Business Venturing, 13(6), 441-466. https://doi.org/10.1016/S0883-9026(97)00061-X

Arora, A., Fosfuri, A., \& Gambardella, A. (1998). Markets for Technology and Their Implications for Corporate Strategy. Ssrn. 1998. https://doi.org/10.2139/ssrn.204848

Baron, R. M., \& Kenny, D. A. (1986). The moderator-mediator variable distinction in social psychological research: conceptual, strategic, and statistical considerations. Journal of Personality and Social Psychology, 51(6), 1173-1182. https://doi.org/10.1037/0022-3514.51.6.1173

Chesbrough, H. (2006). Open innovation: a new paradigm for understanding industrial innovation, in Chesbrough, H. W., Vanhaverbeke, W., \& West, J. (Eds): Open innovation: researching a new paradigm. Oxford: Oxford University Press.

Chesbrough, H. W., Vanhaverbeke, W., \& West, J. (2006). Open innovation: researching a new paradigm. Oxford: Oxford University Press.

Chesbrough, H., \& Crowther, A. K. (20016). Beyond high tech: early adopters of open innovation in other industries. $R \& D$ Management, 36(3), 229-236. https://doi.org/10.1111/j.1467-9310.2006.00428.x

Cockburn, I. M. (2004). The changing structure of the pharmaceutical industry. Health Affairs, 23(1), 10-22. https://doi.org/10.1377/hlthaff.23.1.10

Cooke, P. (2003). Biotechnology clusters, 'Big Pharma' and the knowledge-driven economy. International Journal of Technology Management, 25, 65-80. https://doi.org/10.1504/IJTM.2003.003090

de Bettignies, J. E., \& Brander, J. A. (2007). Financing entrepreneurship: Bank finance versus venture capital. Journal of Business Venturing, 22(6), 808-832. https://doi.org/10.1016/J.JBUSVENT.2006.07.005

Ebersberger, B., Bloch, C., Herstad, S. J., \& Van de Velde, E. (2012). Open innovation practices and their effect on innovation performance. International Journal of Innovation and Technology Management, 9(6), 1250040. https://doi.org/10.1142/S021987701250040X

Ernst \& Young. (2018). News release - EY - Margins of pharmaceutical companies are continuing to decline the future lies in new ecosystems - EY - Switzerland; 2018. Retrieved April 11, 2019, from https://www.ey.com/ch/en/newsroom/news-releases/news-release-ey-margins-of-pharmaceutical-companies -are-continuing-to-decline

Festel, G. (2011). Founding angels as early stage investment model to foster biotechnology start-ups. Journal of Commercial Biotechnoly, 17(2), 165-171. https://doi.org/10.1057/jcb.2011.2

Fudickar, R., \& Hottenrott, H. (2019). Public research and the innovation performance of new technology based firms. Journal of Technology Transfer, 44(2), 326-358. https://doi.org/10.1007/s10961-018-9695-z

Galambos, L, Sturchio, L., \& Jeffrey, L. (1998). Pharmaceutical firms and the transition to biotechnology: A study in strategic innovation. Business History Review, 72(2), 250-278. https://doi.org/10.2307/3116278

Gambardella, A. (1995). Science and Innovation: The US Pharmaceutical Industry During the 1980s. Cambridge: 
Cambridge University Press. https://doi.org/10.1017/CBO9780511522031

Gertler, M. S., \& Vinodrai, T. (2009). Life sciences and regional innovation: one path or many? European Planning Studies, 17(2), 235-261. https://doi.org/10.1080/09654310802553514

Harrison, R. T., Mason, C. M., \& Girling, P. (2004). Financial bootstrapping and venture development in the software industry. Entrepreneurship \& Regional Development, 16(4), 307-333. https://doi.org/10.1080/0898562042000263276

Hossain, M. (2012). Performance and potential of open innovation intermediaries. Procedia - Social and Behavioral Sciences, 58,754-764. https://doi.org/10.1016/j.sbspro.2012.09.1053

Jacobs, S. R., Weiner, B. J., Reeve, B. B., Hofmann, D. A., Christian, M., \& Weinberger, M. (2015). Determining the predictors of innovation implementation in healthcare: a quantitative analysis of implementation effectiveness. BMC Health Service Research, 15(6), 1-13. https://doi.org/10.1186/s12913-014-0657-3

Kale, D. (2012). Innovative capability development in the indian pharmaceutical industry. International Journal of Innovation and Technology Management, 9(2), 1-19. https://doi.org/10.1142/S0219877012500137

Khanna, I. (2012). Drug discovery in pharmaceutical industry: productivity challenges and trends. Drug Discovery Today, 17(19-20):1088-1102. https://doi.org/10.1016/J.DRUDIS.2012.05.007

Klerkx, L., \& Leeuwis, C. (2008). Balancing multiple interests: Embedding innovation intermediation in the agricultural knowledge infrastructure. Technovation, 28(6), 364-378. https://doi.org/10.1016/j.technovation.2007.05.005

Kloyer, M., \& Scholderer, J. (2012). Effective incomplete contracts and milestones in market-distant R\&D collaboration. Research Policy, 4l(2), 346-357. https://doi.org/10.1016/j.respol.2011.11.003

Levinthal, D. A., \& Warglien, M. (2008). Landscape Design: Designing for Local Action in Complex Worlds. Organization Science, 10(3), 342-357. https://doi.org/10.1287/orsc.10.3.342

March, J. G. (1991). Exploration and exploitation in organizational learning. Organization Science, 2(3), 71-87. https://doi.org/10.1287/orsc.2.1.71

Ndou, V., Vecchio, P. D., \& Schina, L. (2011). Open innovation networks: The role of innovative marketplaces for small and medium enterprises' value creation. International Journal of Innovation Technology Management, 8(3), 437-453. https://doi.org/10.1142/S0219877011002404

Onetti, A., \& Zucchella, A. (2014). Business Modeling for Life Science and Biotech Companies: Creating Value and Competitive Advantage with the Milestone Bridge. New York: Routledge. https://doi.org/10.4324/9781315852584

Ovseiko, P. V., Oancea A., \& Buchan, A. M. (2012). Assessing research impact in academic clinical medicine: a study using Research Excellence Framework pilot impact indicators. BMC Health Service, 12, 478. https://doi.org/10.1186/1472-6963-12-478

Papa, A., Mital, M., Pisano, P., \& Del Giudice, M. (2020). E-health and wellbeing monitoring using smart healthcare devices: An empirical investigation. Technological Forecasting and Social Change, 153, 119-226. https://doi.org/10.1016/j.techfore.2018.02.018

Parente, R., Feola, R., \& Petrone, M. (2011). Corporate Governance Models as a Bridge for Linking Academic and Non-Academic Entrepreneurs: The Case of Italian Spin-offs. Industry and Higher Education, 25(2), 119-131. https://doi.org/10.5367/ihe.2011.0036

Parente, R., Feola, R., Cucino, V., \& Gimigliano, A. (2016). R\&D Management in Pharma Industry: the strategic role of CROs. Sinergie, Italian Journal of Management, 34(101), 37-52. https://doi.org/10.7433/s101.2016.03

Piccaluga, A. (2011). La valorizzazione della ricerca scientifica. Milano: Franco Angeli.

Powell, W. W., Koput K. W., \& Smith-Doerr L. (1996). Interorganizational Collaboration and the Locus of Innovation: Networks of Learning in Biotechnology. Admiistrative Science Quarterly, 41(1), 116-145. https://doi.org/10.2307/2393988

Prahalad, C. K., Hamel, G., \& June, M. Y. (1990). The Core Competence of the Corporation. Harvard Business Review, 68(3), 79-91. https://doi.org/10.1007/3-540-30763-X_14

Rao, B., \& Mulloth, B. (2017). The Role of Universities in Encouraging Growth of Technology-Based New Ventures. International Journal of Innovation Technology Management, 14(4), 1750014. 
https://doi.org/10.1142/S0219877017500146

Rosenkopf, L., \& Almeida, P. (2003). Overcoming Local Search Through Alliances and Mobility. Management Science, 49(4), 751-766. https://doi.org/10.1287/mnsc.49.6.751.16026

Schuhmacher, A., Gassmann, O., \& Hinder, M. (2016). Changing R\&D models in research-based pharmaceutical companies. Journal of Translational Medicine, 14(1), 105-115. https://doi.org/10.1186/s12967-016-0838-4

Schuhmacher, A., Germann, P. G., Trill, H., \& Gassmann, O. (2013). Models for open innovation in the pharmaceutical industry. Drug Discovery Today, 18(23-24), 1133-1137.

https://doi.org/10.1016/j.drudis.2013.07.013

Shane, S. (2004). Academic entrepreneurship : university spinoffs and wealth creation. Northampton, MA: Edward Elgar.

Sheriff, M., \& Muffatto, M. (2018). University spin-offs: A new framework integrating enablers, stakeholders and results. International Journal of Innovation Technology Management, 6(3), 1950020. https://doi.org/10.1142/S0219877019500202

Smith, H. L., Romeo, S., \& Bagchi-Sen, S. (2008). Oxfordshire biomedical university spin-offs: An evolving system. Cambridge Journal of Regions, Economy and Society, 1(2), 303-319. https://doi.org/10.1093/cjres/rsn010

Tahvanainen, A. (2004). Growth inhibitors of entrepreneurial academic spin-offs: the case of finnish biotechnology. International Journal of Innovation Technology Management, 1(4), 455-475. https://doi.org/10.1142/S0219877004000283

Vega-Jurado, J., Gutierrez-Gracia, A., \& Fernandez-de-Lucio, I. (2009). Does external knowledge sourcing matter for innovation? Evidence from the Spanish manufacturing industry. Industrial and Corporate Change, 18(6), 637-670. https://doi.org/10.1093/icc/dtp023

Visintin, F., \& Pittino, D. (2014). Founding team composition and early performance of university-Based spin-off companies. Technovation. 34(1), 31-43. https://doi.org/10.1016/J.TECHNOVATION.2013.09.004

Weng, C. S. (2017). Innovation Intermediaries in Technological Alliances. International Journal of Innovation and Technology Management, 14(2). https://doi.org/10.1142/S0219877017400132

Wikhamn, B. R., \& Styhre, A. (2017). Open innovation as a facilitator for corporate exploration. International Journal of Innovation and Technology Management, 21(6), 1-20. https://doi.org/10.1142/S1363919617500426

Wilson, C. (2008). Helping Startups in the Pursuit of Drug Discovery Success, 2008; Retrieved April 5, 2019, from https://pharma.elsevier.com/pharma-rd/helping-startups-pursuit-drug-discovery

Yin, R. K. (1989). Case Study Research: Design and Methods. Newsbury: Ca, SAGE.

Zahra, S. A., \& George, G. (2001). Absorptive capacity: A review, reconceptualization, and extension. Acadademy of Management Review, 27(2), 185-203. https://doi.org/10.5465/amr.2002.6587995

Zeckhauser, R. (2006). Investing in the unknown and unknowable. Capitalism and Society, 1(2), 1-39. https://doi.org/10.2202/1932-0213.1009

Zucker, L. G., Darby, M. R., \& Armstrong, J. S. (2020). Commercializing knowledge: University science, knowledge capture, and firm performance in biotechnology. Management science, 48(1), 138-153. https://doi.org/10.1287/mnsc.48.1.138.14274

\section{Copyrights}

Copyright for this article is retained by the author(s), with first publication rights granted to the journal.

This is an open-access article distributed under the terms and conditions of the Creative Commons Attribution license (http://creativecommons.org/licenses/by/4.0/). 